\title{
An empirical application of entrepreneurial bricolage theory to resource integration using data from small and medium-sized enterprises in Taiwan
}

\author{
Wei-shang Fan \\ Associate Professor \\ Department of Business Administration \\ Nanhua University, Chiayi, Taiwan \\ Kuo-Chung Huang \\ Professor \\ Department of Business Administration \\ Nanhua University, Chiayi, Taiwan \\ Ping-Yu Chiang \\ Ph.D. Student \\ Department of Business Administration \\ Nanhua University, Chiayi, Taiwan
}

\begin{abstract}
By integrating entrepreneurial bricolage theory and relevant entrepreneurial management concepts, this study explores the relationships among entrepreneurship, entrepreneurial ability, bricolage, and the innovation business models of small and medium-sized enterprises (SMEs) from the perspective of resource integration and entrepreneurship and further verifies the mediating effect of bricolage. This study collects 271 valid questionnaires from SME owners and conducts an exploratory and confirmatory analysis of reliability and validity using hierarchical regression analysis and SEM for verification. The empirical evidence shows that (1) entrepreneurship, entrepreneurial ability, and bricolage have significant positive relationships, (2) bricolage and innovation business models have a significant positive relationship, (3) entrepreneurship, entrepreneurial ability, and innovation business models have significant positive relationships, and (4) bricolage partially mediates the relationship between entrepreneurship and innovation business models and fully mediates the relationship between entrepreneurial ability and innovation business models.
\end{abstract}

Keywords: Entrepreneurial Bricolage Theory, Entrepreneurship, Entrepreneurial Ability, Bricolage, Innovation Business Model

\section{Introduction}

Based on the Global Entrepreneurship and Development Index and the International Institute for Management Development (IMD) World Competitiveness Yearbook, this study regards entrepreneurship and entrepreneurial ability as action tendencies that drive bricolage. This study defines starting a business as entrepreneurs using their own ideas to take actions to launch a new company by providing new products or services to achieve their expectations or dreams, and entrepreneurship is defined as the presentation of individual subjective states, including ideas, personalities, styles, and other unique features. However, entrepreneurship is not sufficient, as entrepreneurial ability is also required to start a business. It is important to identify and understand the relationship between resources and competitive advantage (Alavrez and Busenitz, 2001), and entrepreneurs must seek more resources and abilities and maximize their profits through effective allocations(Chandler and Hanks, 1998). Studies such as those of Baron (2006) and Shane and Venkataraman (2000) argue that, to develop new businesses, entrepreneurs need to effectively explore and utilize entrepreneurial opportunities and enter markets in advance to provide increased value to meet market demand. When economic development is difficult, however, business owners can still use their existing resources to operate and develop new product and service portfolios to cope with environmental changes and market demands to meet the goal of continued growth. In many unpredictable situations, business owners often use their own abilities to assemble resources that may or may not have been previously used to confront these limitations and changes and make use of the creativity of bricolage to resolve various problems and constraints. 
According to the resource-based view of strategy management, entrepreneurship can be regarded as part of the resource combination. Many studies based on the valuable, rare, imperfectly imitable, and non-substitutable (VRIN)(e.g., Arend and Levesque 2011; Bakar and Ahmad 2010; Barney 2001;1991)framework regarding the unique importance of resources have moved on from taking the partial use of resources as their basis and have shifted their focus from describing how businesses gain VRIN resources to achieve sustained profitability to understanding how businesses can focus on resource combinations to enhance profitability (Chesbrough, 2010; Kraaijenbrink, Spender, and Groen, 2010; Priem and Butler, 2001; Tsai and and Liao, 2016). However, apart from mentioning the states in which resource integration is appropriate, VRIN-related studies rarely touch upon bricolage. Baker and Nelson (2005) said that entrepreneurs embrace and pursue challenges and that many entrepreneurs can overcome difficulties and challenges with bricolage, and research has shown that the Lévi-Strauss's (1967) concept can be used to explain the bricolage behaviors of small and medium-sized enterprises (SMEs) to create something from nothing when they face resource constraints. As Lennerfors and Rehn (2014) noted, in the context of an economic downturn, some organizations continue to operate using existing resources and even grow to develop new products and services in response tochanges or new market demands, and bricolage regarding businesses' use of available and untapped resources is particularly useful in such unpredictable situations because it leverages creativity to respond to environmental changes.

Past studies, such as those of Storey and Johnson (1987) and Balje and Waasdorp (2001) have shown that small businesses can create more job opportunities than large companies can and that entrepreneurs with entrepreneurship and innovation energy are crucial for driving a country forward and spurring economic growth. Business models play a key role in competition between companies, but many successful business models are now outmoded, as the global environment is rapidly changing (Guo, Su, and Ahlstyom, 2016; Hamel, 2012; Zott and Amit, 2007). There are two research gaps in this area. First, previous studies were traditionally based on the partial use of resources, and although scholars consider partial use to be an important way to combine resources, bricolage is rarely mentioned in the literature. Second, SMEs must have the ability to identify potential opportunities and assemble resources for the bricolage effect to resolve resource constraints to allow for business model innovation. Based on many theoretical and case studies, scholars have found that business models are often innovated through experimental processes (Hayashi, 2009; Sosna, Trevinyo-Rodríguez, and Velamuri, 2010), revealing the precedents for innovative business models. However, the behaviors, actions, and factors that make up this process are unclear and, thus, provide an important direction for exploration. Reshaping business models to maintain business performance is a critical necessity, but it is impossible to innovate business models overnight, and, thus, more understanding of the innovation process is necessary. Understanding how to identify opportunities is therefore an important research question.

This study hopes to close the research gaps mentioned above through statistical inference and interpretations of the correlations among entrepreneurship, entrepreneurial ability, bricolage, and the innovation business models of SME owners and hypothesis testing. This study has the following purposes. First, it aims to explore the correlations between entrepreneurship, entrepreneurial ability, bricolage, and innovation business models. Second, it aims to understand the impacts of entrepreneurship and entrepreneurial ability on bricolage and the impacts of entrepreneurship, entrepreneurial ability, and bricolage on innovation business models. Finally, it aims to test whether bricolage has a mediating effect on the relationships between entrepreneurship and innovation business models and entrepreneurial ability and innovation business models. The research constructs of entrepreneurship and entrepreneurial ability are important indicators for evaluating entrepreneurial development in different countries; for the effect variables, this study uses innovation business models to measures the performance of SMEs. Entrepreneurship is innovative, entrepreneurial ability can lead to innovative behavior, and bricolage can help to create innovation; thus, entrepreneurship and entrepreneurial ability are the antecedent variables, innovation business models is the effect variable, and bricolage is regarded as an action tendency and is used as a mediating variable in this study.

\section{Literature Discussion and Research Hypotheses}

\subsection{Entrepreneurship and Bricolage}

Kirzner (1973), one of the first scholars to advance the theory of entrepreneurship, defines entrepreneurship as sensitivity to opportunities that have not yet been discovered. He used tentacles as an analogy to describe entrepreneurs' sensitivity to the market and argued that entrepreneurs can use that sensitivity to find opportunities in the market. Stevenson, Roberts, and Grousbeck (1989) argued that entrepreneurship means that entrepreneurs not only consider existing resources and capabilities but also integrate external resources and capabilities to seek growth opportunities for value creation. 
Individuals with entrepreneurial qualities can generate innovative ideas and reorganize existing resources and production methods to enable creative destruction (Schumpeter, 1934) or provide new products and services in innovative ways and build a new supply chain to reassemble the industry as a whole (Birkinshaw, 2000), and they also use resources efficiently and deliver value to the market by leveraging innovative thinking (Dollinger, 2003).

Schumpeter said that entrepreneurship is a behavior and can be used to start a business and innovate. Lumpkin and Dess(1996) is an example study that conceptualizes entrepreneurship as the behaviors of individuals or companies that lead to autonomy and innovation. In their research, autonomy leads entrepreneurship, and individuals or organizations require autonomy to make independent decisions and establish visions and goals; innovation is reflected in support for new ideas and creativity in problem solving. Empirical studies on the proactiveness and risk taking of entrepreneurship in companies include that of Zahra, Jennings, and Kuratko(1999). In their work, proactiveness refers to companies' ability to take initiative to grasp market opportunities, and risk taking means that companies are willing to invest resources and can withstand the aftermath of failure. These studies of entrepreneurship behavior, as indicated by Salunke, Weerawardena, and McColl-Kennedy (2013), are mostly used in research on innovation in the manufacturing context and, thus, do not capture the uniqueness of service-oriented enterprises, particularly the adaptive ability required for interactions with customers (Salunke, Weerawardena, and McColl-Kennedy, 2011). Businesses need such a customer-specific approach need to deliver products and services to their customers in search of potential value.

Overall, entrepreneurs aim to grow and develop their SMEs into profitable and sustainable companies (Storey, Watson, and Wynarczyk, 1987). However, Salunke et al. (2013) argue that entrepreneurial initiatives are often constrained by resource-limited environments, whereas Baker and Nelson (2005) and Garud and Karnøe (2003) hold that such changes in circumstances require not only an entrepreneurial attitude but also the ability to recognize and utilize resources, and Gibbert, Hoegl, and Välikangas (2007) believe that aiming to obtain innovative results by leveraging the effects of entrepreneurial bricolage shows that entrepreneurs can actively combine resources, expand markets, and view changes as opportunities. As entrepreneurs persistently refuse to be hindered by limits and resource constraints (DiDomenico, Haugh, and Tracey, 2010), they need to create bothtangible and intangible resources (Blindenbach-Driessen and Van den Ende, 2006) to obtain new resources (Baker and Nelson, 2005; Hsiao, Ou, and Wu, 2017). Taking these findings into account, the relationship between entrepreneurship and bricolage is assumed as follows.

Hypothesis 1: Entrepreneurship has a positive and significant impact on bricolage.

\subsection{Entrepreneurial Ability and Bricolage}

Entrepreneurial ability refers to the skills and qualifications that entrepreneurs need to start a business. These qualifications include understanding the relationship between organizational resources and competitive advantage (Alvarez and Busenitz, 2001) and seeking to identify a variety of resources and capabilities (Siu and Bao, 2008) to effectively configure resources to maximize benefits. However entrepreneurial ability must constantly evolve and improve over timeto cope with environmental changes. Entrepreneurship is a continuous process from launching a business to ensuring that the company thrives to supporting its sustainable development, all of which require the dynamic evolution of entrepreneurial abilities. Entrepreneurs must constantly accumulate lessons from the problemsolving process and learn to improve their own capabilities to meet new challenges in the future.

Entrepreneurial ability has always been an ambiguous concept in the literature on entrepreneurship and business management and has a variety of meanings and definitions (Mitchelmore and Rowley, 2010). For example, Garima (2017) and Bird (1995) defined it as the knowledge, skills, and attitudes needed to successfully complete a job. Miao and $\mathrm{Yu}$ (2009) took overall economic development into account and divide entrepreneurial ability into the core competencies of entrepreneurship (including disruptive creation, risk taking, and learning ability) and the necessary abilities for entrepreneurship (including interpersonal interactions, leadership, organizational skills, and expression skills). Sarasvathy, Dew, Velamuri, and Venkataraman (2003) proposed the definition of opportunity recognition, discovery, and creation based on supply and demand. Baron (2006) considered that the opportunity must be innovative, fit for market needs, and viable. Tsai, Hsieh, and Hsu (2008) defined entrepreneurial ability as the ability to identify, develop, and evaluate opportunities, which means that entrepreneurs must be able to master opportunities in the external environment and make good use of them to create value.

In summary, Liu and Hsieh (2006) pointed out that one of the constraints facing entrepreneurs is acquiring resources and effectively exploring and utilizing opportunities to increase value to meet market demand for new businesses (Baron, 2006; Lin, Hsieh, Liu, and Guo, 2010). Entrepreneurs require entrepreneurial ability to master resources and take advantage of market opportunities as their competitive advantage (Lien, Fong, and Cheng, 2009). However, in a highly competitive environment, adequate resources are often lacking (Gao, Hsieh, and Zhou, 2016), and the most important part of entrepreneurial bricolage is the ability to provide solutions to resolve constraints and achieve innovative results with limited resources (Hsiao, Ou, and Wu, 2017; Lin, 2015; Salunke et al., 2013). 
Entrepreneurs use their own abilities to explore and utilize bricolage opportunities and recombine existing resources to deal with their constraints. Thus, entrepreneurial ability and bricolage are assumed to have the following relationship. Hypothesis 2: Entrepreneurial ability has a positive and significant impact on bricolage.

\subsection{Bricolage and Innovation Business Models}

An, Zhao, Cao, Zhang, and Liu (2018) argued that business owners can use bricolage and opportunity recognition to influence companies themselves and that they can assemble resources, reconstruct resource learning activities, and develop subjective knowledge of the available resources by leveraging their entrepreneurial spirits. This research perspective has some implications. First, entrepreneurs can make their own decisions, use their own experiences to face environmental changes, and constantly learn to transform and reshape their abilities to assemble the resources at hand and reorganize their use to obtain innovative resources to solve problems and overcome restrictions. Second, individuals and organizations observe different influences of the learning environment on bricolage and opportunity recognition, and opportunity identification is also an entrepreneurial ability (Sarasvathy et al., 2003; Tsai et al., 2008). Entrepreneurs can follow the path of resource-action-purpose, leverage bricolage based on their own abilities, and try new alternatives to reorganize and reuse resources to deal with new problems and opportunities (Baker and Nelson, 2005; Tu and Hung, 2012). Thus, entrepreneurs' abilities develop dynamically and change as their abilities and environments change, and they can address problems and constraints in innovative ways by exploring, evaluating, and taking advantage of opportunities.

Teece (2010) defines an innovation business model as a process of continuous value creation, delivery, and acquisition. To innovate business models, entrepreneurs must leverage their abilities to discover and identify opportunities and to combine resources for bricolage to seize opportunities (Amit and Zott, 2001; George and Bock, 2011). Entrepreneurs can assemble resources by leveraging entrepreneurial bricolage effects to foster business model innovation (Go et al., 2016), and entrepreneurs and businesses have been endeavoring to understand the importance of business model innovation and truly innovate business models (Amit and Zott, 2012; Chesbrough, 2010). Wu, Liu, and Zhang (2017) viewed bricolage as an important source of competitive advantage that can help companies build the right skills to quickly rebuild their resource portfolios under resource constraints. The theory of entrepreneurial bricolage holds that entrepreneurs leverage their abilities to creatively use existing resources and combine resources to create value to improve disadvantageous situations and resolve limitations (Baker and Nelson, 2005; Garud and Karnøe, 2003; Hsiao, $\mathrm{Ou}$, and $\mathrm{Wu}, 2017)$. Ou (2015) also noted that awakening the potential values of resources, changing their values, and developing diversified ways of using them is the essence of business model innovation. Thus, bricolage and innovation business models are expected to have the following relationship.

Hypothesis 3: Bricolage has a positive and significant impact on innovation business models.

\subsection{Entrepreneurship, Entrepreneurial Ability, and Innovation Business Models}

Business models explain how businesses operate, create customers, and earn profits (Casadesus-Masanell and Ricart, 2010; Magretta, 2002). The common themes touched on by many studies include how businesses operate or provide activities, how they provide value for customers and potential customers, and how they gain long-term profits and competitive advantage (Davis and Spekman, 2003; Osterwalder, Pigneur and Tucci, 2005; Stewart and Zhao, 2000). Ou and $\mathrm{Su}$ (2017) argued that business models are based on value creation and value acquisition and that their core lies in meeting users' needs and creating value for users. Business models play an important role in companies' competitive advantage (Ahlstrom and Ding, 2014; Hamel, 2012; Zott and Amit, 2007). Because of the rapid pace of globalization, fierce competition, and rapid changes in the market environment, companies have difficulties reshaping or innovating their business models.

Thus, identifying opportunities to create new business models is an important issue that showcases a business owner's entrepreneurial ability. Important factors for business model success include exploring and identifying necessary factors in the market and evaluating and utilizing a model to be close to customers to tap into innovative development needed in the future. Entrepreneurs can take advantage of an imbalance of market supply and demand to identify potential opportunities and use these opportunities to develop or create new goods and services that have not yet emerged to develop new market opportunities. Moreover, before supply and demand signs present themselves, entrepreneurs have already identified ways to create market opportunities to gain an advantage (Sarasvathy et al., 2003).

In summary, Schumpeter (1934) believed that the most important aspect of entrepreneurs was their spirit and that their contribution was combining resources to create new opportunities and business models. However, if entrepreneurs want to seize business opportunities to create value, they need to innovate business models, leverage their abilities to explore, and take advantage of opportunities, which they can achieve through innovative transaction contents, structure, and management (Zott and Amit, 2010). 
For example, the usual cash transactions were transformed into credit card payments and, later, face recognition. In terms of entrepreneurship as a form of resource combination within the scope of strategic management theory, entrepreneurs can use their abilities and partially leverage the resource-based view. As mentioned by Lennerfors and Rehn (2014), the focus has shifted from describing how businesses gain resources within the VRIN framework to achieve sustained profitability to understanding how businesses can combine resources to enhance their profitability (Chesbrough, 2010; Kraaijenbrink et al., 2010; Priem and Butler, 2001; Tsai and Liao, 2016). As mentioned, entrepreneurship, entrepreneurial ability, and innovation business models are assumed to have the following relationships.

Hypothesis 4: Entrepreneurship has a positive impact on innovation business models. Hypothesis 5: Entrepreneurial ability has a positive impact on innovation business models.

\subsection{Bricolage as a Mediator}

As the anthropologist Lévi-Strauss (1967) noted, when executing a plan, craftsmen use the tools or materials at hand and keep materials that are not useful now but will be used in the future, which shows that they cherish resources, make good use of them, and increase and create new resource value. The concept of bricolage, which is both a habit to be developed and a coping mechanism, was thereby created. Baker and Nelson (2005) defined bricolage in management as a combination of existing resources to handle new issues and opportunities. Studies such as those of Wu et al. (2017), Hsiao, Ou, and Wu (2017), Guo et al. (2016), and Lennerfors and Rehn (2014) argued that bricolage could address a lack of resources and enable innovations to resolve constraints and problems. However, it is important to understand how the bricolage system works and what factors individuals, organizations, or companies use to leverage bricolage.

As time is continuous and dynamic and situations can constantly arise, a corresponding mechanism that can be applied at the individual level is needed for organizations, company management, or even national governance. This cognitive mechanism is also called a habit; habits can be categorized by purpose as either efficiency or effect mechanisms. The former focuses on speed (observing whether a response is fast or slow), whereas the latter focuses on results (observing whether the direction of the implemented results is right or wrong). Each habit represents a cognitive mechanism. The efficiency (fast) mechanism develops habits to save time, whereas the effect mechanism develops habits to determine whether a way of handling environmental changes is correct. However, bricolage is an action tendency. Given the continual and dynamic model of resource-action-purpose (Baker and Nelson, 2005; Tu and Hung, 2012), bricolage requires advanced decision-making and combines thought and action, as in the decision-making and execution process. Business owners leverage their entrepreneurship and entrepreneurial ability to take action as a means of carrying out bricolage to achieve a certain purpose. This response model forms a mechanism when its purpose is realized. Business owners can then utilize this mechanism to resolve limitations and problems when encountering the same or similar events and situations. Considering the perspectives and studies mentioned above, bricolage is believed to serve as a mediator in this process. Hence, this study puts forward the following hypotheses.

Hypothesis 6: Bricolage has a mediating effect between entrepreneurship and innovation business models. Hypothesis 7: Bricolage has a mediating effect between entrepreneurial ability and innovation business models.

\section{Research Methods}

\subsection{Research Sample and Data}

This study was conducted using random sampling, with owners of SMEs in Taiwan as the main subjects. Through the student outreach association of Chiayi City under Taiwan Ministry of Education, we were able to use a student support group set up by SME owners to make connections. We ensured that the questionnaires were truly filled in by owners of SMEs, and we leveraged the networks of the business owners in the supporting group, including their supply chain networks and external business activities. For example, SMEs in the manufacturing industry are downstream of raw material manufacturers and upstream of product distributors, use equipment suppliers and service providers for equipment maintenance, and have other business dealings; a company's external activities can include engagements with different associations or organizations, such as the rubber association and industry associations and trade unions at the county or city level. From November 2017 to April 2018, a total of 373 questionnaires were distributed, and 297 were recovered. Among them, 271 were valid questionnaires, implying a recovery rate of $72.65 \%$. According to the summary statistics of the control variables in this study, 181 of the business owners are male, accounting for $66.8 \%$ of the total, whereas 90 owners are women, accounting for $33.2 \%$ of the total. In terms of education, $68(25.1 \%)$ business owners only went to high school or vocational school, $171(63.1 \%)$ have college or university degrees, and $32(11.8 \%)$ hold master's degrees (or above). 
Additionally, 50 enterprises have been operating for less than three years, accounting for $18.5 \%$ of the total; 113 have been operating for three to five years, accounting for $41.7 \%$ of the total; 94 businesses have been operating for six to ten years, comprising $34.7 \%$ of the total; and 14 companies have been operating for more than ten years, accounting for $5.2 \%$ of the total. Finally, 119 companies have fewer than 30 employees, accounting for $43.9 \%$ of the total; 116 businesses have 31 to 50 employees, comprising $42.8 \%$ of the total; 33 companies have 51 to 100 people, accounting for $12.2 \%$ of the total; and three enterprises have 101 to 200 employees, comprising $1.1 \%$ of the total. For details, please refer to Table 1.

Table 1 Data for the control variables

\begin{tabular}{|c|c|c|c|}
\hline $\begin{array}{c}\text { Basic } \\
\text { information }\end{array}$ & Answers & Number & $\begin{array}{c}\text { Proportion } \\
(\%)\end{array}$ \\
\hline \multirow[t]{2}{*}{ Gender } & Male & 181 & 66.8 \\
\hline & Female & 90 & 33.2 \\
\hline \multirow[t]{3}{*}{ Education } & $\begin{array}{c}\text { High } \\
\text { school/vocational } \\
\text { school }\end{array}$ & 68 & 25.1 \\
\hline & College/ university & 171 & 63.1 \\
\hline & $\begin{array}{c}\text { Master's (and } \\
\text { above) }\end{array}$ & 32 & 11.8 \\
\hline \multirow{4}{*}{$\begin{array}{l}\text { Age of the } \\
\text { company }\end{array}$} & Less than 3 years & 50 & 18.5 \\
\hline & 3 to 5 years & 113 & 41.7 \\
\hline & 6 to 10 years & 94 & 34.7 \\
\hline & Over 10 years & 14 & 5.2 \\
\hline \multirow{4}{*}{$\begin{array}{l}\text { Size of the } \\
\text { company }\end{array}$} & Less than 30 & 119 & 43.9 \\
\hline & 31 to 50 & 116 & 42.8 \\
\hline & 51 to 100 & 33 & 12.2 \\
\hline & 101 to 200 & 3 & 1.1 \\
\hline
\end{tabular}

Note: $\mathrm{N}=271$

\subsection{Research Variables and Measurement}

This study has four variables. The first independent variable is Entrepreneurship (EN), defined as entrepreneurs' ability to make decisions, solve problems and organize resources using innovative ideas, and adapt to market responses and take necessary risks. Four question items were chosen to measure EN, following Lumpkin and Dess (1996) and Salunke et al. (2013). The second independent variable is Entrepreneurial Ability (EA), defined as an entrepreneur's ability to find more resources, identify and grasp opportunities, and effectively allocate resources for maximal benefits, following Sarasvathy et al. (2003) and Baron (2006). Three question items were chosen to measure this variable. The mediating variable is Bricolage (BE), defined as entrepreneurs combining existing resources to tackle various problems and constraints. Six question items were selected to measure this variable, following Wu et al. (2017). The dependent variable refers is Innovation Business Models (IBM), defined as an entrepreneur's ability to discover and identify customer needs to seize innovation and profitability opportunities. Three question items were selected to measure this variable, following Zott and Amit (2010) and Guo et al. (2016). The questionnaire for this study used a Likert sevenpoint scale, ranging from a minimum of one point to a maximum of seven points, including "strongly disagree," "disagree," "slightly disagree," "neutral," "slightly agree," "agree," "strongly agree."

\subsection{Reliability and Validity}

This study first performed an exploratory analysis on the collected questionnaires. The four research variables include $\mathrm{EN}$, based on four question items; EA, with three question items; BE, with six question items; and IBM, with three question items. The eigenvalues of the four variables range from 2.323 to 4.386 , explaining $73.104 \%$ to $78.310 \%$ of the total variance. Cronbach's alpha coefficient was used to measure the internal consistency of the various factors, with $\alpha$ ranging from 0.854 to 0.926 , all of which are greater than the standard value of 0.7 (Nunnally, 1978). In addition, this study used confirmatory factor analysis (CFA) to further evaluate the composite reliability (CR) and convergent validity of these four variables. The CR values of the variables ranged from 0.854 to 0.927 , all of which are greater than 0.6 (Bagozzi and Yi, 1988); the factor loadings ranged from 0.764 to 0.903 , all of which are greater than 0.7 (Nunnally, 1978); and the average variance extracted (AVE) ranged from 0.661 to 0.688 , all of which are greater than 0.5 and in line with the benchmark (Fornell and Larcker, 1981). 
These results confirm the combined reliability and convergent validity. For details, see Table 2. Moreover, as shown by Table 3, the square root of the AVE of each construct is between 0.813 and 0.829 , all of which exceed the correlation coefficients of those constructs. The results show that all constructs meet the criteria and exhibit differential validity (Hair, Black, Babin, Anderson, and Tatham, 2006).

\section{Table 2 Method and Verification}

\begin{tabular}{|c|c|}
\hline Item & CFA factor loading \\
\hline \multicolumn{2}{|l|}{$\mathbf{E N}(\alpha=0.896 ; \mathrm{CR}=0.898 ; \mathrm{AVE}=0.688)$} \\
\hline 1.I can be highly discretionary in decision-making. & 0.790 \\
\hline 2. I can be highly resilient to the uncertainties of the & 0.874 \\
\hline future. & 0.878 \\
\hline 3. I can solve problems in innovative ways. & 0.769 \\
\hline $\begin{array}{l}\text { 4. I can adapt to the external environment and think } \\
\text { about countermeasures. }\end{array}$ & \\
\hline $\mathbf{E A}(\alpha=0.861 ; \mathrm{CR}=0.866 ; \mathrm{AVE}=0.685)$ & 0.778 \\
\hline $\begin{array}{l}\text { 1. I am able to use established physical resources } \\
\text { when starting a business. }\end{array}$ & 0.903 \\
\hline 2. I am able to use established operating resources & \\
\hline when starting a business. & 0.796 \\
\hline \multicolumn{2}{|l|}{$\begin{array}{l}\text { 3. I am able to look for business opportunities in a } \\
\text { changing environment. }\end{array}$} \\
\hline$\underline{\mathbf{B E}}(\alpha=0.926 ; \mathrm{CR}=0.927 ; \mathrm{AVE}=0.678)$ & 0.764 \\
\hline $\begin{array}{l}\text { 1. I can use existing resources to meet new } \\
\text { challenges. }\end{array}$ & 0.850 \\
\hline 2. I can use other resources to take on broader & 0.840 \\
\hline $\begin{array}{l}\text { challenges (e.g., interpersonal and social networking, } \\
\text { etc.). }\end{array}$ & 0.838 \\
\hline $\begin{array}{l}\text { 3. I can use existing resources to deal with new } \\
\text { problems. }\end{array}$ & 0.814 \\
\hline $\begin{array}{l}\text { 4. I can find a viable solution to solve new problems } \\
\text { and challenges. }\end{array}$ & 0.831 \\
\hline 5. I can combine existing resources to handle all & \\
\hline kinds of challenges. & 0.787 \\
\hline 6. I can put together resources that are not intended to & 0840 \\
\hline $\begin{array}{l}\text { be used to complete new challenges. } \\
\text { IBM }(\alpha=0.854 ; \mathrm{CR}=0.854 ; \mathrm{AVE}=0.661)\end{array}$ & 0.840 \\
\hline $\begin{array}{l}\text { 1. My business model provides a new mix of } \\
\text { products, services, and information. }\end{array}$ & 0.812 \\
\hline $\begin{array}{l}\text { 2. I introduce new consumption ideas and } \\
\text { innovations into our business model. }\end{array}$ & \\
\hline $\begin{array}{l}\text { 3. I introduce new operating processes, procedures, } \\
\text { and norms into my business model. }\end{array}$ & \\
\hline
\end{tabular}

Table 3 Mean Value, Standard Deviation, Pearson's Correlation Coefficient, and Differential Validity

\begin{tabular}{lcccccc}
\hline \multicolumn{1}{c}{ Construct } & Mean Value & Standard Deviation & A & B & C & D \\
\hline A Entrepreneurship (EN) & 4.39 & 1.08 & $(0.829)$ & & & \\
B Entrepreneurial Ability (EA) & 4.28 & 1.20 & $0.778^{* * *}$ & $(0.828)$ & & \\
CBricolage (BE) & 4.18 & 1.04 & $0.572^{* * *}$ & $0.550^{* * *}$ & $(0.823)$ & \\
D Innovation Business Model (IBM) & 4.47 & 1.03 & $0.626^{* * *}$ & $0.563^{* * *}$ & $0.610^{* * * *}$ & $(0.813)$ \\
\hline
\end{tabular}

Note: $\mathrm{N}=271 ; \mathrm{p}<0.05 ; \mathrm{p}<0.01 ; \mathrm{p}<0.001$

the diagonal value is the square root of the AVE of the latent variable 


\section{Research Results}

\subsection{Descriptive Statistics and Relevant Analysis}

Table 3 shows the mean value, standard deviation, Pearson's correlation coefficient, and square root of the AVE for each variable. The results indicate significant positive correlations between entrepreneurship and bricolage $(r=0.572, p$ $<0.001)$, entrepreneurship and innovation business models $(\mathrm{r}=0.626, \mathrm{p}<0.001)$, entrepreneurial ability and bricolage $(r=0.550, p<0.001)$, entrepreneurial ability and innovation business models $(r=0.563, p<0.001)$, and bricolage and innovation business models $(\mathrm{r}=0.610, \mathrm{p}<0.001)$. The results are consistent with the preliminary inference of this study, as they show that there are indeed positive and significant relationships between each variable. Thus, the hypotheses are found to be initially supported.

\subsection{Hypothesis Testing}

Regression analysis can be used to test the hypotheses, and all variables are centralized to avoid potential multicollinearity problems (Aiken and West, 1991). This study used variance inflation factor (VIF) analysis to examine multicollinearity. The maximum VIF is 1.38, which is below the standard of ten (Neter, William, and Kutner, 1985). Thus, there are no significant multicollinearity problems. The indicator figures of $\chi^{2}=166.907, \mathrm{df}=98, \mathrm{p}=0.000$, $\mathrm{GFI}=0.927$, AGFI=0.898, NFI=0.947, $\mathrm{CFI}=0.977$, RMR=0.068, RMSEA=0.051, CMINDF=1.703show that the hypothetical model in Figure 1, which is to be validated in this study, has a good fit. Furthermore, the question items within each construct have factor loadings above 0.50 , statistically significant $\mathrm{p}$-values $(\mathrm{P}<0.01)$, no standardization coefficients greater than 0.95 , and positive error variations, and no unreasonable values or violations of the estimates are found.

This study tested the research hypotheses separately using structural equation modeling analysis. Hypothesis 1 (H1) states that entrepreneurship has a positive and significant impact on bricolage. As shown in Table 4, the path coefficient value for $\mathrm{H} 1$ is 0.365 , and its t-value is 3.491 , implying that this path estimate is significant and, thus, validating $\mathrm{H} 1$. The higher the degree of SME owners' entrepreneurship is, the higher the degree of bricolage is. Hypothesis 2 (H2) states that entrepreneurial ability has a positive and significant impact on bricolage. As indicated by Table 4, the path coefficient value for $\mathrm{H} 2$ is 0.267 , with a t-value of 2.563 , implying that this path estimate is significant, validating $\mathrm{H} 2$. Thus, the higher the entrepreneurial ability of SME owners is, the higher the degree of bricolage is. Hypothesis 3 (H3) states that bricolage has a positive and significant impact on innovation business models. As shown in Table 4, the path coefficient value for $\mathrm{H} 3$ is 0.359 , with a t-value of 4.938 , indicating that the path estimate is significant and, hence, validating H3. Thus, the more bricolage resources that SME owners have, the more innovative the business model is. Hypothesis 4 (H4) states that entrepreneurship has a positive and significant impact on innovation business models. Table 4 shows that the path coefficient value for $\mathrm{H} 4$ is 0.347 , with a t-value of 3.322 , showing that the path estimate is significant. Thus, H4, which indicates that if SME owners have higher entrepreneurship, their business models are more innovative, is supported. Hypothesis 5 (H5) states that entrepreneurial ability has a positive and significant impact on innovation business models. Table 4 shows that the path coefficient value for H5 is 0.096 , with a t-value of 0.944 , implying that the path estimate is not significant, and, thus, H5 is not supported. Instructural equation modeling, a mediating effect can be similar to an indirect effect, but these two effects do have some differences. If the correlation coefficient between the independent and dependent variables is zero, there may also be an indirect effect, whereas a mediating effect implies that the independent and dependent variables must have a significant correlation. Table 3 shows that there is a significant correlation between entrepreneurial ability and bricolage $(\mathrm{r}=0.550, \mathrm{p}<0.001)$, and this study uses the overall model effect result (Table 5) to verify whether hypotheses 6 and 7 regarding mediating effects hold.
$0.365^{* * *}$
$0.347^{* * *}$
$0.359^{* * *}$
$0.267^{* *}$

0.096

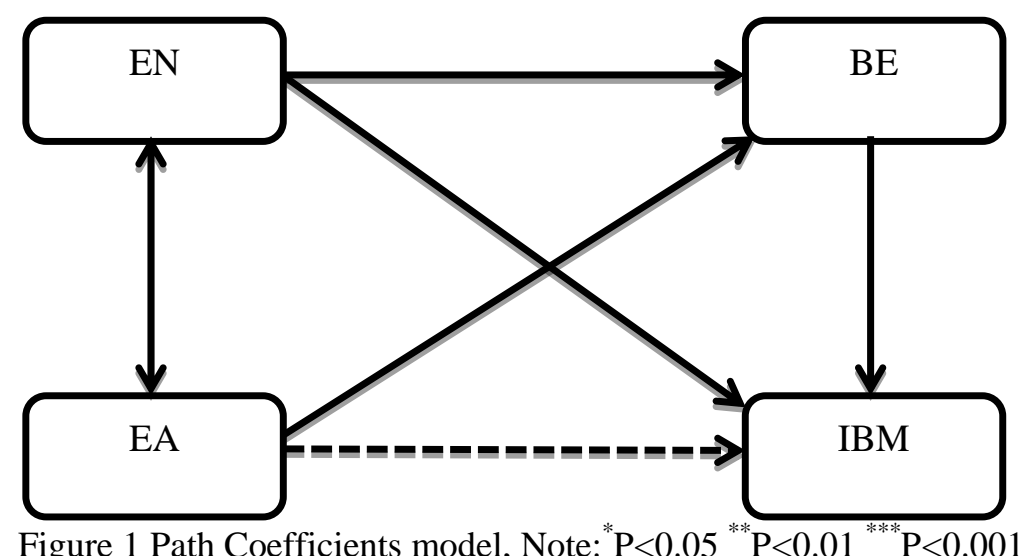


Table 4 Overall Path Analysis

\begin{tabular}{c|c|c|c|c}
\hline Hypothesis & Path & Hypothetical relationship & Path coefficient /T value & Hypothesis validity \\
\hline H1 & EN $\rightarrow \mathrm{BE}$ & Positive and significant & $0.365^{* * * *} / 3.491$ & Valid \\
\hline H2 & EA $\rightarrow \mathrm{BE}$ & Positive and significant & $0.267^{* *} / 2.563$ & Valid \\
\hline H3 & BE $\rightarrow$ IBM & Positive and significant & $0.359^{* * * * *} / 4.938$ & Valid \\
\hline H4 & EN $\rightarrow$ IBM & Positive and significant & $0.347^{* * * *} / 3.322$ & Valid \\
\hline H5 & EA $\rightarrow$ IBM & Positive and significant & $0.096 / 0.944$ & Invalid \\
\hline
\end{tabular}

Note: Entrepreneurship (EN); Entrepreneurial Ability (EA); Bricolage (BE); Innovation Business Model (IBM) p $<0.05 ;^{* *} \mathrm{p}<0.01 ;{ }^{* * *} \mathrm{p}<0.001$

Table 5 Overall Model Results

\begin{tabular}{cccccc}
\hline $\begin{array}{c}\text { Latentdependent } \\
\text { variable }\end{array}$ & $\begin{array}{c}\text { Latentindependent } \\
\text { variable }\end{array}$ & $\begin{array}{c}\text { Direct } \\
\text { effect }\end{array}$ & Indirect effect & $\begin{array}{c}\text { Total } \\
\text { effect }\end{array}$ & $\begin{array}{c}\text { Hypothesis } \\
\text { validity }\end{array}$ \\
\hline \multirow{2}{*}{ IBM } & EN & $0.347^{*}$ & $0.131\left(0.365^{*} 0.359\right)$ & 0.478 & H4 and H6 valid \\
& EA & 0.096 & $0.096\left(0.267^{*} 0.359\right)$ & 0.192 & $\begin{array}{c}\text { H5 invalid; H7 } \\
\text { valid }\end{array}$ \\
& BE & $0.359^{*}$ & - & 0.359 & H3 valid \\
\hline BE & EN & $0.365^{*}$ & - & 0.365 & H1 valid \\
& EA & $0.267^{*}$ & - & 0.267 & H2 valid \\
\hline
\end{tabular}

Note:* represents $\mathrm{P}<0.05 ;-$ represents no effect

\section{Conclusions}

This study aims to use the empirical evidence that entrepreneurial bricolage can serve to integrate resources to explore whether entrepreneurship and the entrepreneurial abilities of SME owners contribute to bricolage and innovation business models and to further understand the mediating role of bricolage. SMEs are generally resilient and quick to adapt but are generally considered to have disadvantages, such as small scales and a lack of resources. However, studies have found that SMEs have many unrecognized or not-fully-utilized resources (DiDomenico et al., 2010). Thus, business owners need to make quick decisions, execute to find the right materials, and assemble them to solve their current problems (Baker and Nelson, 2005; Garud and Karnøe, 2003; Hsiao, Ou, and Wu, 2017). A statistical analysis of a sample of 271 SME owners had the following findings. First, the predicted effects of entrepreneurship and the entrepreneurial abilities of SME owners on bricolage were found to be supported; the higher the degree of entrepreneurship of the business owners surveyed was, the more actively they engaged in bricolage behaviors, and the greater the entrepreneurial ability of the business owners surveyed was, the better the effects of the bricolage were. Additionally, hypothesis 3 regarding the predicted effect of SME owners utilizing bricolage on business model innovation was found to be supported; in other words, the more actively business owners engaged in bricolage behaviors, the more innovative the implemented business models were. Hypothesis 4 regarding the predicted effect of SME owners' entrepreneurship on innovation business models was also found to be supported, which means that when SME owners have high entrepreneurial spirit, the implemented business models are more innovative. In addition, hypothesis 5 regarding the predicted effect of SME owners' entrepreneurial ability on innovation business models was not significant because bricolage fully mediated entrepreneurial ability in the structural model. Thus, when SME owners actively engage in bricolage, the impact on the innovativeness of the business model is greater than that of their entrepreneurial ability. As for hypotheses 6 and 7, this study analyzed the overall structural equation model to find that bricolage has a partial mediating effect in the relationship between entrepreneurship and innovation business models but a fully mediating effect in the relationship between entrepreneurial ability and innovation business models. Thus, bricolage is a process variable driven by the antecedent variable of entrepreneurship to change the innovation business model. As entrepreneurial ability is fully mediated by bricolage, bricolage is also an outlet for displaying entrepreneurial ability. The empirical results also support the above analysis. On the whole, this study explores the empirical evidence of the resource integration of Taiwan's SME owners based on the theory of entrepreneurial bricolage, and the analytical results support all of the research hypotheses except for hypothesis 5, as that relationship was fully mediated in the structural model and was not supported. 


\subsection{Theoretical Implications}

When it comes to the resource-based and dynamic capability views, Tsai and Liao (2016) pointed out that these views can be complementary to each other rather than mutually exclusive. Overall, the resource-based view assumes that manufacturers can conceptualize a group of resources within the VRIN framework, and with resources as the basis for action, manufacturers can occupy, accumulate, and solidify special resources to obtain competitive advantages .The dynamic capability view holds that businesses actively update, adjust, and learn new capabilities in response to changes in technologies and the market. However, some studies combining both views have not explained the reasoning behind and implications for the reorganization (Chen, $\mathrm{Wu}$, and Hsiang, 2010). This study empirically confirms that bricolage can be used to explain the integration and combination of resources, and actively updating and learning new abilities to maintain competitive advantage in response to environmental changes requires the abilities to recognize, discover, and create (Baron, 2006; Sarasvathy et al., 2003; Tsai et al., 2008). The theory of entrepreneurial bricolage has been applied in many resource-related studies, such as those of Hsiao, Ou, and Wu (2017), Hsiao, Ou, and Chen (2014), Wu et al. (2017), Guo et al. (2016), Lennerfors and Rehn (2014), Salunke et al. (2013), and Chen et al. (2010). Previous studies of the application of bricolage theory to new product development, service innovation, exploration of positioning, and resolving constraints have been validated.

Through a literature review, this study integrates latent constructs such as entrepreneurship, entrepreneurial ability, bricolage, and innovation business models into a specific research topic. Based on empirical evidence regarding resources, this study focuses on the entrepreneurship of SME owners and their entrepreneurial ability to leverage entrepreneurial bricolageto innovate business models, and it analyzes the mediating effect of bricolage, which has rarely been discussed in the study of entrepreneurial bricolage and entrepreneurship management. Furthermore, this study used structural equation modeling to verify the relationship between the direct and indirect paths, and the results show that bricolage has a partial mediating effect on entrepreneurship. This result suggests that the indirect effect of bricolage is less than its direct effect and confirms that bricolage is an action tendency that needs to be manipulated by the antecedent variable of entrepreneurship (a behavioral factor that drives a process factor to integrate resources) to obtain the effect of innovation business models. In addition, the results indicate that bricolage has a full mediating effect on entrepreneurial ability, which means that bricolage can directly affect innovation business models without entrepreneurial ability. It can be inferred from this study that bricolage is an outlet for showcasing entrepreneurial ability, thus closing the gap related to the definition and explanation of entrepreneurial ability in the literature. Finally, as the environment continuously changes over time, entrepreneurship and entrepreneurial ability can still be used as indicators for evaluating the vitality and competitiveness of individuals, organizations, and the national economy. The theoretical model set up by this study and the research results can complement the theory of entrepreneurial bricolage, the resource-based view, and the dynamic capability view.

\subsection{Practical Implications}

In Eastern management philosophy and within that cultural environment, Chinese people are deeply influenced by Confucianism, which focuses on individual practices as an element of management, and the subjective decision-making and execution of SME owners can affect the development of an entire company. When an enterprise, organization, or entrepreneur faces problems but has limited resources, many options are available. According to the theory of entrepreneurial bricolage, organizations facing limitations can leverage bricolage to transform constraints into opportunities, resolve crises, and lift restrictions (Hsiao et al., 2014; Hsiao, Ou, and Su, 2017; Hsiao, Ou, and Wu, 2017). For example, Mr. Terry Gou has grown Foxconn from a small factory for TV parts to a world-renowned company and one of Taiwan's top 100 companies. Enrestec was seen as an underdog from the beginning because many people thought that unwanted tires could not be commercialized, but those tires have been transformed into an environmentally friendly moneymaker. For such improperly recognized resources, entrepreneurs choose to further the cause despite years of losses. They discover opportunities by utilizing their ability to recognize opportunity, overcoming resource constraints by leveraging bricolage, changing and creating the use and value of resources, and innovating business models to expand their markets.

Resources are scarce for countries and even for individuals. Taiwan, for example, lacks rich minerals and oil but rather relies on talent to drive its economic development. Thus, the entrepreneurship and entrepreneurial ability of Taiwan's business owners are important. The Global Entrepreneurship Index (GEI) and the IMD World Competitiveness Yearbook indicate that Taiwan is among the best in the Asia-Pacific region in this regard. Owing to resource constraints, it is becoming more important to cherish resources, increase the value of the resources in use, and develop bricolage habits to create something from something (change existing resources) or create something from nothing (create from existing resources) to solve problems and constraints and develop mechanisms that automatically correspond with environmental changes. 
By this line of reasoning, resource bricolage is an important issue for business owners and organizations. For example, An et al. (2018) point out that business leaders can use bricolage to identify new opportunities, as bricolagecan be an effective driving force for businesses to overcome resource constraints and motivate companies to actively innovate and update their strategies to enhance their risk-taking abilities. Echo the three elements of the entrepreneurial bricolage model constructed by Baker and Nelson (2005): making do, combining resources for new purposes, and using resources at hand. These elements can be used to overcome resource shortages and environmental constraints and even achieve resource construction and innovate under disadvantage. This study also empirically confirms that bricolagecan be used as an integration approach, as entrepreneurs need to utilize their entrepreneurship and entrepreneurial ability to leverage bricolage. Through bricolage, entrepreneurs can recombine various resources to resolve their own problems and constraints to innovate business models and obtain greater profits and to achieve long-lasting development and create mechanisms to respond to environmental changes.

Acknowledgement: The author would like to thank all of the owners of the SMEs involved. Special thanks also go to Mr. Li Yu-Hao and Ms. Liu Ru-Jyun for their help and assistance.

\section{References}

Ahlstrom, D., \& Ding, Z. (2014). Entrepreneurship in China: An overview. International Small Business Journal, 32(6), 610-618.

Aiken, L. S., \& West, S. G. (1991). Multiple regression: testing and interpreting interactions. Newbury Park, California: Sage.

Alvarez, S. A., \&Busenitz, L. W. (2001).The entrepreneurship of resource-based theory.Journal of Management, 27(6), 755-775.

Amit, R., \&Zott, C. (2001).Value creation in e-business. Strategic Management Journal, 22(6-7), 493-520.

Amit,R., \&Zott, C. (2012).Creating value through business model innovation. Sloan Management Review, 53(3), 4149.

An, W., Zhao, X., Cao, Z., Zhang, J., \& Liu, H. (2018). How bricolage drives corporate entrepreneurship: the roles of opportunity identification and learning orientation. Product Development and Management Association, 35(1), 49-65.

Arend, Richard. J.,\&Moren Levesque (2011). Is the Resource-based View a Practical Oorganizational Theory? Organization Science, 21(4), 913-930.

Bagozzi, R. P., \& Yi, Y. (1988).On the evaluation of structural equation models. Journal of the Academy of Marketing Science, 16(1), 74-94.

Bakar, Lily, Julienti Abu., \&Hartini Ahmad (2010).Assessing the Relationship betweenFirm Resources and Product Innovation Performance: A Resource-based View,Business Process Management Journal. 16(3), 420-435.

Baker, T., \&Nelson, R. E. (2005).Creating something from nothing: resource construction through entrepreneurial bricolage.Administrative Science Quarterly, 50(3), 329-366.

Balje, S., \&Waasdorp, P. (2001).Entrepreneurship in the 21st century.In Entrepreneurship in the Netherlands, new economy: new entrepreneurs! EIM Business \& Policy Research and the Ministry of Economic Affairs, 29-49.

Barney, Jay B., (1991). Firm Resources and Sustained Competitive Advantage.Journal of Management, 14(1), 33-46.

Barney, Jay B., (2001). Resource-based Theories of Competitive Advantage: A Ten-year Retrospectiveon the Resource-based View.Journal of Management, 27(6), 643-650.

Baron, R. A. (2006).Opportunity recognition as pattern recognition: how entrepreneurs connect the dots to identify new business opportunities. Academy of Management Perspectives, 20(1), 104-119.

Bird, B. (1995).Towards a theory of entrepreneurial competency. Advances in Entrepreneurship, Firm Emergence and Growth, 2, 51-72.

Birkinshaw, J. (2000). Entrepreneurship in the global firm. London: Sage Publications.

Blindenbach-Driessen, F., \& Van den Ende, J. (2006).Innovation in project-based firms: the context dependency of success factors. Research Policy, 35(4), 545-561.

Casadesus-Masanell, R., \&Ricart, J. E. (2010).From strategy to business models and onto tactics.Long Range Planning, 43(2-3), 195-215.

Chandler, G. N., \& Hanks, S. H. (1998). An examination of the substitutability of founder human and financial capital in emerging business ventures. Journal of Business Venturing, 13(5), 353-369.

Chen, Y. W., Wu, S. H., \& Hsiang, W.H. (2010). The resource-based view of the resource bricolage and value creation for the innovative product development: a case of "Taiwan opens up the wings". Journal of Technology Management, 15(20), 1-20. 
Chesbrough, H. (2010). Business model innovation: opportunities and barriers. Long Range Planning, 43(2-3), 354363.

Davis, E. W., \&Spekman, R. E. (2003).The extended enterprise: gaining competitive advantage through collaborative supply chains, 1st. Upper Saddle River, NJ: Prentice-Hall.

Di Domenico, M., Haugh, H., \& Tracey, P. (2010). Social bricolage: theorizing social value creation in social enterprises. Entrepreneurship: Theory and Practice, 34(4), 681-703.

Dollinger, M. J. (2003). Entrepreneurship: strategies and resources (3rd ed.). Upper Saddle River, NJ: Prentice Hall.

Fornell, C., \&Larcker, D. F. (1981).Evaluating structural equation models with unobservable variables and measurement error. Journal of Marketing Research, 18(1), 39-50.

Gao, G. Y., Xie, E., \& Zhou, K. Z. (2015). How does technological diversity in supplier network drive buyer innovation? Relational process and contingencies. Journal of Operations Management, 36, 165-177.

Garima, S. (2017). Multidimensional competency construct for social entrepreneurs: a logistic regression approach. Kasetsart Journal of Social Sciences,Available online January, 122018.

Garud, R., \&Karnøe, P. (2003).Bricolage versus breakthrough: distributed and embedded agency in technology entrepreneurship. Research Policy, 32(2), 277-300.

George, G., \& Bock, A. J. (2011).The business model in practice and its implications for entrepreneurship research. Entrepreneurship: Theory and Practice, 35(1), 83-111.

Gibbert, M., Hoegl, M., \&Välikangas, L. (2007).In praise of resource constraints. MIT Sloan Management Review, 48(3), 15-17.

Guo, H., Su Z., \&Ahistrom, D. (2016).Business model innovation: the effects of exploratory orientation, opportunity recognition, and entrepreneurial bricolage in an emerging economy. Asia Pacific Journal of Management, 33(2), 533-549.

Hair, J. F., Black, W. C., Babin, B. J., Anderson, R. E., \& Tatham, R. L. (2006). Multivariate data analysis (6th ed.). New Jersey: Pearson Educational International.

Hamel, G. (2012). What matters now: how to win in a world of relentless change, ferocious competition, and unstoppable innovation hardcover. San Francisco: Jossey-Bass.

Hayashi, A. M. (2009). Do you have a plan B? MIT Sloan Management Review, 51(1), 10-11.

Hsiao, R. L., Ou, S. H., \& Chen, H. F.(2014).Innovating under disadvantages: bricolage behaviors in Van Gogh art curation. Sun Yat-Sen Management Review, 22(2), 323-367.

Hsiao, Ruey-Lin, Ou, S. H., \& Su, Y. (2017). Inversing the powerful: process of resource construction through bricolage. NTU Management Review, 27(4), 1-32.

Hsiao, R. L., Ou, S. H., \& Wu, Y. K. (2017). Making-do within adversity: resource constraints as a source of innovation. Sun Yat-Sen Management Review, 25(1), 219-268.

Kirzner, I. M. (1973).Competition and entrepreneurship. Chicago, IL: University Of Chicago Press.

Kraaijenbrink, J., Spender, J. C.,\&Aard, G. (2010). The resource-based view: a review of and assessment of its critiques. Journal of Management, 36(1), 349-372.

Lennerfors, T. T.,\& Rehn, A. (2014).Chance interventions - on bricolage and the state as an entrepreneur in a declining industry.Culture and Organization, 20(5), 377-391.

Lévi- Strauss, C. (1967). The savage mind. Chicago, IL: University of Chicago Press.

Liang, J., Farh, C. I. C., \&Farh, J. L. (2012).Psychological antecedents of promotive and prohibitive voice: a two-wave examination. Academy of Management Journal, 55(1), 71-92.

Lien, Y. C., Fong, C. M., \& Cheng, C. C. (2009). Entrepreneurship study and family business issues: review and perspective. Organization and Management, 2(2), 51-76.

Lin, T. L. (2015). Research in entrepreneurial networks dynamic and stylistic innovation: by small shoes' firms in Taiwan. Management Review, 32(1), 1-24.

Lin, T. L., Hsieh, M. C., Liu, H. Y., \&Kuo, S. I. (2010). A study of entrepreneurship, complementary industries, international market opportunities and brand building: Taiwan sports, recreation and leisure industry case manufacturers for example. Fu Jen Management Review, 13(3), 85-110.

Liu, C. Y., \& Hsieh, R. M. (2006). Review and foresight for the entrepreneurship management research: an exploration of theory and framework. Entrepreneurship Management Review, 1(1), 1-43.

Lumpkin, G. T., \&Dess, G. G. (1996). Clarifying the entrepreneurial orientation construct and linking it to performance. Academy of Management Review, 21(1), 135-172.

Magretta, J. (2002). Why business models matter.Harvard Business Review, 80(5), 86-92.

Miao, Q., \& Yu, C. (2009).Entrepreneurial competency: perspectives, structures and practices. Presented at IEEE 2009 International Conference on Management and Service Science International Conference (MASS’ 09), 1-4. 
Mitchelmore, S., \& Rowley, J., (2010). Entrepreneurial competencies: a literature review and development agenda. International Journal of Entrepreneurial Behavior and Research, 16(2), 92-111.

Neter, J., Wasserman, W., and Kutner, M. H. (1985).Applied linear statistical models: regression, analysis of variance, and experimental design. Homewood, IL: Richard Irwin.

Nunnally, J. C. (1978). Psychometric theory (2nd ed ). New York: McGraw-Hill.

Osterwalder, A., Pigneur Y., \&Tucci, C. L. (2005).Clarifying business models: origins, present, and future of the concept.Communications of the Association for Information Systems, 16(1), 1-25.

$\mathrm{Ou}$, S. H. (2015). Summoning resources from a deep sleep: business model innovation underlying 'lady first'. Sun YatSen Management Review, 23(1), 225-267.

Ou, S. H., \& Su, H. T. (2017). Hybrid business model innovation: the cross-boundary mechanism for over-the-top organizations. Management Review, 36(4), 1-15.

Priem, R., \& Butler, J. (2001). Is the resource-based view a useful perspective for strategic management research? Academy of Management Review, 26(1), 22-40.

Salunke, S., Weerawardena, J., \& McColl-Kennedy, J. R. (2011).Towards a model of dynamic capabilities in innovation-based competitive strategy: insights from project-oriented service firms. Industrial Marketing Management, 40(8), 1251-1263.

Salunke, S., Weerawardena, J., \& McColl-Kennedy, J. R. (2013).Competing through service innovation: the role of bricolage and entrepreneurship in project-oriented firms. Journal of Business Research, 66(8), 1085-1097.

Sarasvathy, S. D., Dew, N., Velamuri, S. R., \&Venkataraman, S. (2003). Three views of entrepreneurial opportunity, In Z. J. Acs, \& D. B. Audretsch (Eds.), Handbook of entrepreneurship research: an interdisciplinary survey and introduction, 1 (pp. 141-160). New York, NY: Springer.

Schumpeter, J. A. (1934). The theory of economic development,New Brunswick, NJ: Transaction Publishers.

Shane, S., \&Venkataraman, S. (2000) The promise of entrepreneurship as a field of research. Academy of Management Review, 25(1), 217-226.

Siu, W. S., \&Bao, Q. (2008). Network strategies of small Chinese high-technology firms: a qualitative study. Journal of Product Innovation Management, 25(1), 79-102.

Sosna, M., Trevinyo-Rodríguez, R. N., \&Velamuri, S. R. (2010). Business models innovation through trial-and error learning: the Naturhouse case. Long Range Planning, 43(2-3), 383-407.

Stevenson, H. H., Roberts, M. J., \&Grousbeck, H. I. (1989). New business ventures and entrepreneur (3rd ed.). Homewood, IL: Irwin.

Stewart, D. W., \& Zhao, Q. (2000).Internet marketing, business models, and public policy.Journal of Public Policy \& Marketing, 19(2), 287-296.

Storey, D., \& Johnson, S. (1987). Small and medium-sized enterprises and employment creation in the EEC countries: summary report. EC Commission, Programme of Research and Actions on the Development of the Labour Market Study, 85, 407.

Storey, D., Watson, R., \&Wynarczyk, P. (1988). Fast growth small businesses: case studies of 40 small firms in north east England. Department of Employment, Research Paper: 67, London.

Teece, D. (2010). Business models, business strategy and innovation.Long Range Planning, 43(2-3), 172-194.

Tsai, M. T., Hsieh, W. P., Lee, K. W., \& Hsu, D. T. (2008). The relationship between entrepreneurship and entrepreneurial performance: the integrating perspective of entrepreneurial motivation, ability, and personality traits.Entrepreneurship Management Review, 3(3), 29-65.

Tsai, C. A., \& Liao, M. K. (2016).Examining firms' strategies for competitive advantages through resource-based view and dynamic capability view under different environments.Management Review, 35(1), 47-72.

Tu, M. F., \& Hung, S. C. (2012). Creating something from something: how ITRI Enacts B.B.C. strategies to transform the technology development program.Management Review, 29(3), 229-254.

Wu, L., Liu, H.,\& Zhang, J. (2017).Bricolage effects on new-product development speed and creativity: the moderating role of technological turbulence. Journal of Business Research, 70, 127-135.

Zahra, S. A., Jennings, D. F., \&Kuratko, D. F. (1999). The antecedents and consequences of firm-level entrepreneurship: the state of the field. Entrepreneurship: Theory and Practice, 24(2), 47-67.

Zott, C., \& Amit, R. (2007).Business model design and the performance of entrepreneurial firms. Organization Science, 18(2), 181-199.

Zott, C., \& Amit, R. (2010). Business model design: an activity system perspective, Long Range Planning, 43(2-3), 216-226. 